EDITORIAL

\title{
Statins for heart failure: at the crossroads between cholesterol reduction and pleiotropism?
}

\author{
S von Haehling, S D Anker
}

\section{Statins are being hailed as the new aspirin-but are they beneficial for patients with heart failure?}

S atins, also known as 3-hydroxy-3-methylglutaryl-coenzyme A (HMG-CoA) reductase inhibitors, were originally designed to lower plasma cholesterol. Over the last few years these drugs have been widely hailed as the aspirin of the new millennium. Interestingly enough, a patient asked me recently in our outpatients' department: "Doctor, could you please prescribe me a statin, because I understand that they are generally good for you." Marketing seems to have attained its goal.

Lovastatin was the first statin to be approved by the US Food and Drug Administration (FDA) in 1987. Five different statins are currently available in most European countries, and the development of new substances is well underway. Additionally, as a sixth statin on the US market, rosuvastatin was approved by the FDA in August 2003. Rosuvastatin has also been licensed in some European countries over the last months.

Statins are commonly considered safe and well tolerated. Mild side effects, however, may occur in up to $15 \%$ of statin treated patients, with symptoms related to the digestive system being the most frequently reported side effects. However, cerivastatin had to be withdrawn from the market for safety reasons in August 2001. When considering the use of statins in patients with heart failure, however, safety concerns go into a completely different direction. The idea of beneficial effects of cholesterol in chronic heart failure is based on the endotoxin-lipoprotein hypothesis. ${ }^{1}$ Higher concentrations of total serum cholesterol, low density lipoprotein, and triglycerides were predictors of better (not worse) survival in recent studies in heart failure, $^{23}$ independent of disease aetiology, age, left ventricular ejection fraction, and exercise capacity. ${ }^{2}$ On the other hand, a lot of evidence has accumulated over the last years to suggest potential benefits of statin administration in this disease.

\section{CARDIOVASCULAR RISK REDUCTION}

Statin treatment consistently reduces cardiovascular risk. ${ }^{45} \mathrm{~A}$ reduction in recurrent coronary events has been observed as early as 16 weeks after the initiation of treatment. ${ }^{6}$ This timeframe is too short to ascribe to the positive effects of cholesterol reduction alone. ${ }^{7}$ The idea of statin s.vonhaehling@imperial. ac.uk
Heart 2005;91:1-2. doi: 10.1136/hrt.2004.042515

mediated effects beyond cholesterol lowering, so-called pleiotropic effects, has thus triggered an avalanche of research in recent years, and the chapter of investigation into statins is far from being finished.

Some of the statin mediated effects are attributable to the inhibition of cholesterol biosynthesis. Indeed, substrates downstream from mevalonate in the synthesis cascade contribute to a number of other metabolic pathways. ${ }^{8}$ Geranylgeranyl-pyrophosphate is a typical example. It serves as a lipid attachment to the GTP binding protein rho, which is involved in stress fibre formation, ${ }^{9}$ monocyte adhesion, and transmigration through the endothelium. ${ }^{10}{ }^{11} \mathrm{~A}$ number of studies have described anti-inflammatory properties of statins. Some of these substances reduce $\mathrm{C}$ reactive protein (CRP) concentrations independently of cholesterol reduction. ${ }^{12}$ Furthermore, some statins reduce the production of pro-inflammatory cytokines, which is of special interest in the treatment of chronic heart failure. Indeed, this perturbation is known to be accompanied by elevated plasma levels of tumour necrosis factor $\alpha$, interleukin-1, and interleukin- $6,{ }^{13}$ all of which have been demonstrated to be down regulated in in vivo and in vitro models by statin application. ${ }^{14}{ }^{15}$

\section{EFFECTS ON ENDOTHELIAL FUNCTION}

The overall effects of statins on endothelial function merit special attention. These drugs have been shown to decrease neointimal thickening in models of carotid injury ${ }^{16}{ }^{17}$ and also to reduce clinical events and angiographic restenosis after coronary stent implantation. ${ }^{18}$ These effects were attributed to inhibition of smooth muscle cell proliferation. ${ }^{19}$ Recent research has provided insights into the profound effects of statins on endothelial cell function. The induction of nitric oxide gene transcription, which yields an increased production of the vasodilating molecule nitric oxide, is one among a number of mechanisms contributing to an improvement in endothelial function..$^{20}$ Another mechanism involves antioxidant properties. Atorvastatin has recently been shown to up regulate the expression of catalase, an antioxidant enzyme, at the mRNA and protein level in an

Abbreviations: CORONA, controlled rosuvastatin multinational trial in heart failure; CRP, C reactive protein; FDA, Food and Drug Administration; GISSI-HF, Gruppo Italiano per lo studio della sopravvivenza nell' insulficienza cardiaca; HMG-CoA, 3-hydroxy-3methylglutaryl-coenzyme A; PUFA, polyunsaturated fatty acids 
in vitro model. ${ }^{21}$ This downregulated the production of reactive oxygen species, which are known to inhibit nitric oxide activity.

In this issue of Heart, Tousoulis and colleagues ${ }^{22}$ report the results of a prospective, randomised, placebo controlled study on the effects of four weeks treatment with $10 \mathrm{mg}$ atorvastatin once daily in patients with chronic heart failure. This comparatively low dose of atorvastatin reduced plasma concentrations of cholesterol by $23 \%$ within four weeks of treatment. It is tempting to speculate that even lower doses of atorvastatin than that used by Tousoulis and colleagues will still confer pleiotropic effects, possibly without lowering plasma cholesterol. Although their study was unblinded and failed to reach one of its primary end points, they provide interesting clinical insights into statin mediated mechanisms. ${ }^{22}$ Absolute blood flow values remained unchanged after treatment. This might be due to the comparatively short treatment period. However, atorvastatin treatment affected the coagulation and fibrinolysis system in that it decreased the plasma concentrations of antithrombin III, protein C, coagulation factor $\mathrm{V}$, tissue plasminogen activator, and plasminogen activator inhibitor type 1 . It is interesting to note that statins interfere with coagulation factors independently of where the production site is located. Future studies will tell us whether this has clinical consequences.

\section{LARGE SCALE TRIALS}

The available data strongly suggest that there is an urgent need for a prospective large scale trial to evaluate statin administration in patients with heart failure. Indeed, rosuvastatin is currently under investigation in the CORONA (controlled rosuvastatin multinational trial in heart failure) study. This study aims to recruit more than 4900 patients with heart failure of ischaemic aetiology, who will be randomised in a double blind fashion to rosuvastatin $(10 \mathrm{mg}$ once daily) or placebo. Patients will be followed up for approximately three years, with cardiovascular death, nonfatal myocardial infarction, and non-fatal stroke being the primary end points. A similar study is the prospective, multicentre, randomised, double blind GISSI-HF trial (Gruppo Italiano per lo studio della sopravvivenza nell'insufficienza cardiaca), which aims to investigate the impact of n-3 polyunsaturated fatty acids (PUFA) and rosuvastatin in patients with chronic heart failure. Patients will be randomised in two steps to: (1) n-3 PUFA ( 1 g once daily) or placebo; and (2) rosuvastatin (10 mg once daily) or placebo. Indeed, the GISSI-prevenzione trial showed that three year treatment with low dose n-3 PUFA was associated with a significant reduction of total mortality by $21 \%$ in patients who survived a recent myocardial infarction. ${ }^{23}$ Moreover, n-3 PUFA is also known to exert antiarrhythmic and anti-inflammatory effects.

There has been some concern about lowering the availability of coenzyme Q. ${ }^{24}$ Its production is affected by any statin treatment. The most important concern in heart failure, however, remains that lowering plasma lipoproteins and cholesterol too much may be detrimental. The evaluation of the right dose for the heart failure patient may therefore remain an issue for future studies.

\section{Authors' affiliations}

S von Haehling, S D Anker*, National Heart \& Lung Institute, Department of Clinical Cardiology, Imperial College School of Medicine, London, UK

*Also at the Division of Applied Cachexia Research, Department of Cardiology, Charité Medical School, Campus Virchow-Klinikum, Berlin, Germany

\section{REFERENCES}

1 Rauchhaus M, Coats AJ, Anker SD. The endotoxin-lipoprotein hypothesis. Lancet 2000;356:930-3.

2 Rauchhaus M, Clark AL, Doehner W, et al. The relationship between cholesterol and survival in patients with chronic heart failure. J Am Coll Cardiol 2003;42:1933-40.

3 Horwich TB, Hamilton MA, Maclellan WR, et al. Low serum total cholesterol is associated with marked increase in mortality in advanced heart failure. J Card Fail 2002;8:216-24.

4 Shepherd J, Cobbe SM, Ford I, et al for the West of Scotland Coronary Prevention Study Group. Prevention of coronary heart disease with pravastatin in men with hypercholesterolemia. N Engl J Med 1995;333:1301-7.

5 The Long-Term Intervention with Pravastatin in Ischaemic Disease (LIPID) Study Group. Prevention of cardiovascular events and death with pravastatin in patients with coronary heart disease and a broad range of initial cholesterol levels. N Engl J Med 1998;339:1349-57.

6 Schwartz GG, Olsson AG, Ezekowitz MD, et al. Effects of atorvastatin on early recurrent ischemic events in acute coronary syndromes: the MIRACL study: a randomised controlled trial. JAMA 2001;285:1711-18.

7 Vaughan CJ, Gotto AM, Basson CT. The evolving role of statins in the management of atherosclerosis. J Am Coll Cardiol 2000;35:1-10.

8 Goldstein JL, Brown MS. Regulation of the mevalonate pathway. Nature 1990;343:425-30.

9 Amano M, Fukata Y, Kaibuchi K. Regulation and functions of Rho-associated kinase. Exp Cell Res 2000;261:44-51.

10 Strey A, Janning A, Barth $H$, et al. Endothelial Rho signaling is required for monocyte transendothelial migration. FEBS Lett 2002;517:261-6.

11 Worthylake RA, Lemoine $S$, Watson JM, et al. RhoA is required for monocyte tail retraction during transendothelial migration. J Cell Biol $2001 ; 154: 147-60$

12 Ridker PM, Rifai N, Clearfield M, et al for the Air Force/Texas Coronary Atherosclerosis Prevention Study Investigators. Measurement of C-reactive protein for the targeting of statin therapy in the primary prevention of acute coronary events. N Engl J Med 2001;344:1959-65.

13 Anker SD, von Haehling S. Inflammatory mediators in chronic heart failure: an overview. Heart 2004;90:464-70.

14 Pahan K, Sheikh FG, Namboodiri AM, et al. Lovastatin and phenylacetate inhibit the induction of nitric oxide synthase and cytokines in rat primary astrocytes, microglia, and macrophages. J Clin Invest 1997; 100:2671-9.

15 Chan DC, Watts GF, Barrett PH, et al. Effect of atorvastatin and fish oil on plasma high-sensitivity C-reactive protein concentrations in individuals with visceral obesity. Clin Chem 2002;48:877-83.

16 Indolfi C, Cioppa A, Stabile E, et al. Effects of hydroxymethylglutaryl coenzyme A reductase inhibitor simvastatin on smooth muscle cell proliferation in vitro and neointimal formation in vivo after vascular injury. J Am Coll Cardiol 2000;35:214-21.

17 Bustos C, Hernandez-Presa MA, Ortego M, et al. HMG-CoA reductase inhibition by atorvastatin reduces neointimal inflammation in a rabbit model of atherosclerosis. J Am Coll Cardiol 1998;32:2057-64.

18 Walter DH, Schachinger V, Elsner M, et al. Effect of statin therapy on restenosis after coronary stent implantation. Am J Cardiol 2000;85:962-8.

19 Corsini A, Pazzucconi F, Pfister P, et al. Inhibitor of proliferation of arterial smooth-muscle cells by fluvastatin. Lancet 1996;348:1584.

20 von Haehling S, Anker SD, Bassenge E. Statins and the role of nitric oxide in chronic heart failure. Heart Fail Rev 2003;8:99-106.

21 Wassmann S, Laufs U, Muller K, et al. Cellular antioxidant effects of atorvastatin in vitro and in vivo. Arterioscler Thromb Vasc Biol 2002;22:300-5.

22 Tousoulis D, Antoniades C, Bosinakou E, et al. Effects of atorvastatin on reactive hyperaemia and the thrombosis-fibrinolysis system in patients with heart failure. Heart 2005;91:27-31.

23 GISSI-Prevenzione Trial Investigators. Dietary supplementation with n-3 polyunsaturated fatty acids and vitamin $\mathrm{E}$ after myocardial infarction: results of the GISSI-Prevenzione trial. Lancet 1999;354:447-55.

24 Krum H, McMurray JJ. Statins and chronic heart failure: do we need a largescale outcome trial? J Am Coll Cardiol 2002;39:1567-73. 
ME van der Elst substantially contributed to the design, analysis and interpretation of data, drafting the article and final approval of the version to be published. He will act as guarantor for the paper. ML Bouvy, CJ de Blaey and $A$ de Boer substantially contributed to the design and interpretation of data, revising the article critically for important intellectual content and final approval of the version to be published.

\section{REFERENCES}

1 Anonymous. Demographic Yearbook 1997, English/French ed. New York: Publishing Division United Nations, 1998.

2 AHA. 2002 Heart and stroke statistical update. Dallas: American Heart Association, 2001. http://www.americanheart.org laccessed 27 October 2005).

3 Statline. Population, monthly and yearly data. Statistics Netherlands. http:// statline.cbs.nl (accessed 27 October 2005)

4 Antithrombotics trialist collaboration. Collaborative meta-analysis of randomised trials of antiplatelet therapy for prevention of death, myocardial infarction, and stroke in high risk patients. BMJ 2002;324:71-86.

5 Freemantle N, Cleland J, Young P, et al. $\beta$ Blockade after myocardial infarction: systematic review and meta regression analysis. BMJ 1999;318:1730-7.

6 Mehta RH, Eagle KA. Secondary prevention in acute myocardial infarction. BMJ 1998:316:838-42

7 van der Elst ME, Buurma H, Bouvy ML, et al. Drug therapy for prevention of recurrent myocardial infarction. Ann Pharmacother 2003:37:1465-77.

8 Anand SS, Yusuf S. Oral anticoagulant therapy in patients with coronary artery disease: a meta-analysis. JAMA 1999;282:2058-67.

9 Dagenais GR, Yusuf S, Bourassa MG, et al. Effects of ramipril on coronary events in high-risk persons: results of the Heart Outcomes Prevention Evaluation Study. Circulation 2001;104:522-6.

10 Gottlieb SS, McCarter RJ, Vogel RA. Effect of beta-blockade on mortality among high-risk and low-risk patients after myocardial infarction. N Engl J Med 1998;339:489-97.

11 Goldbourt U, Behar S, Reicher-Reiss H, et al. Early administration of nifedipine in suspected acute myocardial infarction. The Secondary Prevention Reinfarction Israel Nifedipine Trial 2 Study. Arch Intern Med 1993;153:345-53.

12 Dargie HJ. Effect of carvedilol on outcome after myocardial infarction in patients with left-ventricular dysfunction: the CAPRICORN randomised trial. Lancet 2001;357:1385-90.

13 Heart Protection Study Collaborative Group. MRC/BHF Heart Protection Study of cholesterol lowering with simvastatin in 20536 high-risk individuals: a randomised placebo-controlled trial. Lancet 2002;360:7-22.

14 Yusuf S, Sleight P, Pogue J, et al. Effects of an angiotensin-converting-enzyme inhibitor, ramipril, on cardiovascular events in high-risk patients. The Heart Outcomes Prevention Evaluation Study Investigators. N Engl J Med 2000;342:145-53

15 van Bergen PF, Deckers JW, Jonker JJ, et al. Efficacy of long-term anticoagulant treatment in subgroups of patients after myocardial infarction. Br Heart $J$ 1995; 74:117-21

16 Smith $\mathbf{P}$, Arnesen $\mathrm{H}$, Abdelnoor M. Effects of long-term anticoagulant therapy in subgroups after acute myocardial infarction. Arch Intern Med 1992;152:993-7.

17 Pyorala K, De Backer G, Graham I, et al. Prevention of coronary heart disease in clinical practice. Recommendations of the Task Force of the European Society of Cardiology, European Atherosclerosis Society and European Society of Hypertension. Eur Heart J 1994;15:1300-31

18 Smith SC Jr, Blair SN, Bonow RO, et al. AHA/ACC Scientific Statement: AHA/ ACC guidelines for preventing heart attack and death in patients with atherosclerotic cardiovascular disease: 2001 update. A statement for healthcare professionals from the American Heart Association and the American College of Cardiology. Circulation 2001;104:1577-9

19 Wald NJ, Law MR. A strategy to reduce cardiovascular disease by more than $80 \%$. BMJ 2003:326:1419.

20 Hippisley-Cox J, Coupland C. Effect of combinations of drugs on all cause mortality in patients with ischaemic heart disease: nested case-control analysis. BMJ 2005:330:1059-63.

21 Herings RM, Bakker A, Stricker BH, et al. Pharmaco-morbidity linkage: a feasibility study comparing morbidity in two pharmacy based exposure cohorts. $J$ Epidemiol Community Health 1992;46:136-40.

22 Institute for Drug Outcome Research. The Pharmo Database. Pharmo Institute. http://www.pharmo.nl (accessed 27 October 2005)

23 Mantel-Teeuwisse AK, Klungel $\mathrm{OH}$, Verschuren WM, et al. Comparison of different methods to estimate prevalence of drug use by using pharmacy records. J Clin Epidemiol 2001;54:1181-6
24 Herings RM, de Boer A, Stricker BH, et al. A rapid method to estimate the incidence rate and prevalence of insulin-dependent diabetes mellitus in children 0-19 years of age. Pharm World Sci 1995;17:17-9.

25 Maitland-van der Zee AH, Klungel $\mathrm{OH}$, Stricker BH, et al. Repeated nitrate prescriptions as a potential marker for angina pectoris. A comparison with medical information from the Rotterdam Study. Pharm World Sci 2003:25:70-2.

26 Zhang J, Yu KF. What's the relative risk? A method of correcting the odds ratio in cohort studies of common outcomes. JAMA 1998;280:1690-1.

27 Davies HT, Crombie IK, Tavakoli M. When can odds ratios mislead? BMJ 1998;316:989-91.

\section{WEB TOP 10}

www.heartinl.com

These articles scored the most hits on Heart's website during July 2007

1 JBS 2: Joint British Societies' guidelines on prevention of cardiovascular disease in clinical practice

December 2005;91(suppl V):1-52. (Supplement)

2 Treatment of stable angina

I Ben-Dor, A Battler

July 2007:93:868-74. (Education in Heart)

3 Pericardial disease: what the general cardiologist needs to know

EL Ivens, BI Munt, RR Moss

August 2007;93:993-1000. (Education in Heart)

4 Intensive statin therapy in acute coronary syndromes and stable coronary heart disease: a comparative meta-analysis of randomised controlled trials

J Afilalo, AA Majdan, MJ Eisenberg

August 2007;93:914-21. (Systematic review)

5 Impact of blood pressure on the Doppler echocardiographic assessment of severity of aortic stenosis

SH Little, K-L Chan, IG Burwash

July 2007;93:848-55. (Original research)

6 Management of end stage heart failure

EB Friedrich, M Böhm

May 2007;93:626-31. (Education in Heart)

7 Cardiovascular magnetic resonance in the evaluation of heart failure

RG Assomull, DJ Pennell, SK Prasad

August 2007;93:985-92. (Education in Heart)

8 Improving end-of-life care for patients with chronic heart

failure: "Let's hope it'll get better, when I know in my heart of hearts it won' $\mathrm{t}$ "

L Selman, R Harding, T Beynon, F Hodson, E Coady, C Hazeldine, M Walton, L Gibbs, IJ Higginson

August 2007;93:963-7. (Original research)

9 Differential diagnosis of elevated troponins

$S$ Korff, HA Katus, E Giannitsis

July 2006:92:987-93. (Education in Heart)

10 Drug induced QT prolongation and torsades de pointes

YG Yap, AJ Camm

November 2003;89:1363-72. (Education in Heart)

Visit the Heart website for hyperlinks to these articles, by clicking on "Top 10 papers"

www.heartjnl.com 